\title{
Bispectral index in dogs with high intracranial pressure, anesthetized with propofol and submitted to two levels of $\mathrm{FiO}_{2}$
}

\author{
[Índice biespectral em cães com pressão intracraniana elevada, anestesiados com propofol e \\ submetidos a dois níveis de $\mathrm{FiO}_{2}$ ] \\ P.C.F. Lopes $^{1}$, N. Nunes ${ }^{2 *}$, L.G.G.G. Dias ${ }^{1}$, G.B. Pereira Neto ${ }^{1}$, R.M. Almeida ${ }^{1}$, \\ A.L.G. Souza ${ }^{1}$, E.A. Belmonte ${ }^{1}$. \\ ${ }^{1}$ Pós-graduando(a) do Programa de Pós-Graduação - Cirurgia Veterinária \\ Faculdade de Ciências Agrárias e Veterinárias (FCAV) - UNESP \\ Campus de Jaboticabal - Via de Acesso Prof. Paulo Donato Castellane s/n \\ 14884-900 - Jaboticabal, SP \\ ${ }^{2}$ Departamento de Clínica e Cirurgia Veterinária - FCAV, UNESP - Jaboticabal, SP
}

\begin{abstract}
The effects of inspired oxygen fractions $\left(\mathrm{FiO}_{2}\right)$ of 1 and 0.6 on bispectral index (BIS) in dogs with high intracranial pressure, submitted to a continuous rate infusion of propofol were evaluated. Eight dogs were anesthetized on two occasions, receiving, during controlled ventilation, an $\mathrm{FiO}_{2}=1(\mathrm{G} 100)$ or an $\mathrm{FiO}_{2}=$ 0.6 (G60). Propofol was used for induction (10 $\left.\mathrm{mg} \cdot \mathrm{kg}^{-1}, \mathrm{IV}\right)$, followed by a continuous rate infusion $\left(0.6 \mathrm{mg} \cdot \mathrm{kg}^{-1} \cdot\right.$ minute $\left.^{-1}\right)$. After 20 minutes, a fiber-optic catheter was implanted on the surface of the right cerebral cortex to monitor the intracranial pressure, the baseline measurements of BIS values, signal quality index, suppression ratio number, electromyogram indicator, end-tidal carbon dioxide partial pressure, mean arterial pressure, intracranial pressure and cerebral perfusion pressure were taken. Then, the blood flow from the right jugular vein was interrupted in order to increase intracranial pressure and after 20 minutes additional recordings were performed at 15-minute intervals (T0, T15, T30, T45 and T60). The arterial oxygen partial pressure varied according to the changes in oxygen. For the other parameters, no significant differences were recorded. The BIS monitoring was not influenced by different $\mathrm{FiO}_{2}$.
\end{abstract}

Keywords: bispectral index, dog, intracranial pressure, inspired oxygen fraction, propofol

\section{RESUMO}

Avaliaram-se os efeitos das frações inspiradas de oxigênio $\left(\mathrm{FiO}_{2}\right)$ de 1 e 0,6 sobre o índice biespectral (BIS) em cães com pressão intracraniana elevada e submetidos a infusão contínua de propofol. Oito animais foram anestesiados em duas ocasiões, recebendo durante a ventilação controlada $\mathrm{FiO}_{2}=$ 1(G100) ou $\mathrm{FiO}_{2}=0,6$ (G60). Propofol foi usado para indução $\left(10 \mathrm{mg} . \mathrm{kg}^{-1}\right)$ e seguido por infusão contínua $\left(0,6 \mathrm{mg} \cdot \mathrm{kg}^{-1}\right.$ minuto $\left.{ }^{-1}\right)$. Após vinte minutos da implantação do cateter de fibra óptica do monitor de pressão intracraniana, na superfície do córtex cerebral direito, realizaram-se as mensurações basais de BIS, índice de qualidade de sinal, taxa de supressão, eletromiografia, pressão parcial de dióxido de carbono ao final da expiração, pressão arterial média, pressão intracraniana e pressão de perfusão cerebral. Em seguida, interrompeu-se o fluxo sanguíneo da veia jugular direita, para o aumento da pressão intracraniana e depois de 20 minutos, novas mensurações foram realizadas em intervalos de 15 minutos (T0, T15, T30, T45 e T60). A pressão parcial de oxigênio no sangue arterial variou conforme a $\mathrm{FiO}_{2}$. Para os outros parâmetros não foram registradas diferenças significativas. Conclui-se que o monitoramento pelo BIS não foi afetado pelo emprego de diferentes $\mathrm{FiO}_{2}$.

Palavras-chave: cão, frações inspiradas de oxigênio, índice biespectral, pressão intracranina, propofol

Recebido em 17 de julho de 2010

Aceito em 4 de julho de 2011

*Autor para correspondência (corresponding author)

E-mail: newton@fcav.unesp.br 


\section{INTRODUCTION}

The treatment of animals with varying degrees of neurological disorders has become very common in veterinary medicine. In most of these situations they require anesthesia with the correct protocol and thorough monitoring. The high inspired oxygen fraction $\left(\mathrm{FiO}_{2}\right)$ used during anesthesia is a concern, because high oxygen concentration is correlated with a collapse of part of the lung. A low oxygen concentration has been used to avoid this problem (Lopes e Nunes, 2010).

Atelectasis develops with both intravenous and inhalational anesthesia and whether the patient is breathing spontaneously or ventilated mechanically (Strandberg et al., 1986). Lopes et al. (2007) proposed the formation of atelectasis in dogs subjected to a continuous rate infusion (CRI) of propofol $\left(0.7 \mathrm{mg} \cdot \mathrm{kg}^{-1} \cdot \mathrm{minute}^{-1}\right)$ during spontaneous ventilation with $\mathrm{FiO}_{2}$ of 1 or 0.8. However, research proved that the use of prolonged intermittent positive pressure ventilation (IPPV) at normal pressure and volume does not result in atelectasis (Greenfield et al., 1964) and it is practical and successful in dogs (Hopper et al., 2007).

In a situation where there is a collapse of part of the lung, increases in arterial partial pressure of carbon dioxide $\left(\mathrm{PaCO}_{2}\right)$ can also occur (Haskins, 2007), impairing cerebral autoregulation (McCulloch et al., 2000; Harvey et al., 2007) and increasing cerebral blood flow (CBF) (Mi et al., 1998; Harvey et al., 2007). This situation is important because intracranial pressure (ICP) increases can occur due to the changes in blood flow (Shenkin e Bouzarth, 1970) and cerebral blood volume (Smith et al., 1970). In patients with neurological diseases, consideration of the dynamics of ICP, CBF, cerebrospinal fluid production and flow is important in preventing patient morbidity or death (Harvey et al., 2007).

In terms of monitoring methods during general anesthesia, the electroencephalogram (EEG) has been used in various ways to achieve measures of anesthetic depth (March e Muir, 2005; Rosow e Manberg, 2001), but the EEG tracings have been variably altered by hypercapnia states (Mi et al., 1998; Jordan, 1999) sedatives, hypoxia, ischemia and intracranial hypertension (Jordan, 1999).
Most recently, the EEG has been processed using a bispectral analysis (BIS), which was specifically developed to measure the hypnotic effects of anesthesia. The computation of BIS uses signals from the patient's EEG, which are immediately digitized and filtered to avoid artifacts. The BIS is a dimensionless number scaled between 0 and 100, where 0 indicates an isoelectric EEG and 100 represents the normal, conscious state. This can be used to measure the overall response of the central nervous system to drugs, and not the concentration of any particular drug (Rosow e Manberg, 2001). The BIS monitor also shows: signal quality index (SQI) in $\%$, ranging from 0 to 100 ; the suppression ratio number (SR) in \%, calculated to give the user information when the EEG is isoelectric, the electromyogram indicator (EMG) in decibels (db), to record muscular activity as well as high frequency artifacts, and the EEG (Guerrero e Nunes, 2003). Poor SQI combined with increased EMG activity should alert the anesthesiologist to interpret BIS values with care because of possible artifact signal pollution (Hemmweling e Migneault, 2002).

The BIS has been used to monitor anesthesia with proprofol in dogs (Lopes et al., 2008ab). Lopes et al. (2008a), in a study with dogs, concluded that an increase in the propofol infusion rate is related to a decrease in the BIS values and EMG. In canines submitted to continuous infusion of propofol $(0.7 \mathrm{mg} . \mathrm{kg}$ ${ }^{1}$.minute $\left.{ }^{-1}\right)$ and maintained in spontaneous breathing, the use of different $\mathrm{FiO}_{2}(1.0,0.8$, 0.6, 0.4 and 0.21 ) does not impair BIS monitoring (Lopes et al., 2008b). Mi et al. (1998) evaluated humans anesthetized with propofol/fentanyl, supplying $\mathrm{FiO}_{2}$ from 0.3 to 0.35 , and found that the $\mathrm{PaCO}_{2}$ of 24 to $46 \mathrm{mmHg}$ did not interfere in the monitoring of the BIS' anesthetic depth.

However, during surgery, the BIS may fall nearly to zero due to deep anesthesia, hypothermia and cerebral ischemia (Morimoto et al., 2005)' which can be caused by significant ICP increases (Harvey et al., 2007). Additionally, Morimoto et al. (2005) explained that BIS is an indicator of inadequate cerebral perfusion.

Propofol is known for maintaining or decreasing ICP, while it also maintains cerebral perfusion pressure (CPP), in patients with normovolemia 
and under stable hemodynamic condition (McKeage e Perry, 2003). Thus, it may commonly be selected for patients where an increased ICP (Armitage-Chan et al., 2007) is suspected. Although BIS values have shown anesthesia procedure with this drug in healthy canine species, documented experience with high intracranial pressure is limited.

Therefore, this study was designed to assess the bispectral index monitoring dogs with high intracranial pressure, submitted to a continuous infusion of propofol and maintained under controlled ventilation with inspired oxygen fractions $\left(\mathrm{FiO}_{2}\right)$ of 1 or 0.6 .

\section{MATERIAL AND METHODS}

This study was approved by the Institutional Ethics and Animal Welfare Committee of Faculdade de Ciências Agrárias e Veterinárias of Universidade Estadual Paulista "Júlio de Mesquita Filho", Campus Jaboticabal, SP, protocol $n^{\circ}$ 003933-07. After the study the animals were available for adoption.

Eight mature mongrel dogs, four males and four females, weighing $10.1 \pm 2.0 \mathrm{~kg}$, were enrolled in the study. All animals were determined to be healthy based on clinical and laboratorial evaluation. Blood, urine, electrocardiogram and thoracic radiography exams were all done. They were provided with water and regular dog food and kept in individual cages at the Veterinary Teaching Hospital.

The dogs were anesthetized on 2 occasions, $21 \mathrm{~d}$ apart, and received oxygen at an $\mathrm{FiO}_{2}$ of 1.0 $(\mathrm{G} 100)$ or $0.6(\mathrm{G} 60)$ in a randomized crossover fashion.

Anesthesia was induced with 10 mg. $\mathrm{kg}^{-1}$ of propofol (Fresofol 1\%, Fresenius Kabi Brasil Ltda, Campinas, SP, Brazil) administered intravenously (IV). After endotracheal intubation, the dog received oxygen at the assigned $\mathrm{FiO}_{2}$ and a flow of 30 or $50 \mathrm{~mL} . \mathrm{kg}^{-}$ ${ }^{1}$.minute ${ }^{-1}$ through an anesthetic circuit (Ohmeda - Excel 210SE, Madison, EUA - Proc. FAPESP 97/10668-4), that allowed partial rebreathing of gases, equipped with pressure/volumetric ventilator (Ohmeda). The oxygen concentration was checked using gas equipment (DX 2010LCD, Dixtal, Manaus, AM, Brazil - Proc.
FAPESP 02/04625-0). Controlled ventilation began immediately, and the respiratory rate, tidal volume, with a maximum inspiratory pressure of $20 \mathrm{~cm} \mathrm{H}_{2} \mathrm{O}$, were adjusted and fixed to achieve an I:E 1:2 to $1: 3$ and end-tidal carbon dioxide partial pressure $\left(\mathrm{ETCO}_{2}\right)$ of 35 to $45 \mathrm{~mm} \mathrm{Hg}$. $\mathrm{ETCO}_{2}$ was monitored using a respiratory monitor (DX 8100, Dixtal, Manaus, AM, Brazil - Proc. FAPESP 03/11125-7). Adjustments were made in ventilation before the first measurement and, consequently, before intracranial hypertension induction and no more adjustments were made thereafter.

Anesthesia was maintained with a CRI (Infusion Pump 670T, Samtronic Ltda, São Paulo, SP, Brazil) of propofol at a rate of $0.6 \mathrm{mg} . \mathrm{kg}^{-}$ ${ }^{1}$.minute ${ }^{-1}$ IV. The dose of propofol was obtained by previous studies. Additionally, lidocaine (Xylestesin 2\% - Cristália Produtos Químicos Farmacêuticos Ltda - Itapira, SP) infiltration was performed on the right cerebral cortex and the right cervical region.

The dogs were positioned on the left lateral recumbency. For assessment of the ICP, a fiberoptic catheter (Monitor de temperatura-pressão intracraniana, 110-4BT - Integra Neur Camino Labs, San Diego, EUA - Proc. FAPESP 00/01084-3) was surgically implanted in the surface of the right cerebral cortex with the use of an access kit (Integra Neur Camino Labs Proc. FAPESP 00/01084-3), according to the technique described by Rezende (2004). An intra-arterial catheter was then placed in the right tarsal artery to assess the mean arterial pressure (MAP) and to obtain arterial blood for measurements of the $\mathrm{PaCO}_{2}$ and arterial partial pressure of oxygen $\left(\mathrm{PaO}_{2}\right)$ (Roche Omni C blood gas analyzer; Roche Diagnostics, Mannheim, Germany).

Twenty minutes after implanting the fiber-optic catheter, an increase of ICP was induced for the obliteration of the jugular vein. The right jugular vein was exposed surgically and subjected to a provisory ligature consisting of 2 cotton threads $3 \mathrm{~cm}$ apart. The aim of this procedure was to obtain ICP values higher than $15 \mathrm{mmHg}$. Lower values have been considered normal (Johnston et al., 1991; Plochl et al., 1998). The ICP was measured and cerebral perfusion pressure (CPP) was calculated subtracting the ICP value from the MAP. 
The BIS was computed by an Aspect A-2000 XP monitor (A - 2000 XP Bispectral Index Monitor Systems, Inc. Natick, MA, EUA - Proc. FAPESP 02/4625-0). The signal was acquired with a sensor, which had three electrodes, (BIS Pediatric Sensor - Aspect Medical Systems, Inc. Inc. Natick, MA, EUA ) placed as described by Guerrero and Nunes (2003). Thereby, primary electrode was applied to the central forehead between the zygomatic processes. Tertiary, electrode was applied cranially to right ear and secondary electrode at the temporal bone midway between primary and tertiary electrodes.

Before the induction of anesthesia, with animals awake and breathing room air, BIS values were recorded only to eliminate low-voltage electroencephalographic signals, which could result in a false low BIS during anesthesia, as reported by Schnider et al. (1998).

Baseline measurements of ICP, CPP, MAP, $\mathrm{ETCO}_{2}, \mathrm{BIS}, \mathrm{SQI}, \mathrm{EMG}$ and SR were taken immediately before the temporary ligation of the jugular vein. The $\mathrm{PaO}_{2}$ and $\mathrm{PaCO}_{2}$ were recorded only after ICP increases.

The first measurement (T0) was taken twenty minutes after the obliteration of the right jugular vein, and additional recordings were performed at 15-minute intervals for 60 minutes (T15, T30, T45 and T60). Numerical data was subjected to Morrison's multivariate statistical methods $(\mathrm{P}<0.05)$ (Morrison, 1967; Curi, 1980).

Immediately after the end of the anesthesia, the dog's wounds were covered with sterile bandages. Between anesthesia procedures, animals were provided with water and regular dog food and kept in individual cages. Dogs were given carprofen (Rimadyl, 25mg; Pfizer, Guarulhos, São Paulo, Brazil), $4.4 \mathrm{mg} / \mathrm{kg}$ orally once a day (SID) for 3d, and benzathine penicillin G (Billi Farmacêutica, Santo Amaro, São Paulo, Brazil), 40 000U/kg intramuscularly once a day for $5 \mathrm{~d}$. One person was responsible for surgical wound care, medication and taking the dogs for a walk twice a day.

\section{RESULTS}

Before the right jugular vein was obliterated, the ICP means were registered for G100,
$15 \pm 5 \mathrm{mmHg}$, and for $\mathrm{G} 60,13 \pm 4 \mathrm{mmHg}$. Twenty minutes after the interruption of the blood flow in the jugular vein (T0), the ICP values increased $46.67 \%$ in $\mathrm{G} 100$, and $38.46 \%$ in G60, and they remained the same for the next few moments. No differences in ICP or CPP were registered between groups or among moments.

The BIS value recorded before the induction of anesthesia was $98 \pm 0.4$ for G100 and G60. The BIS, EMG, SQI, SR, MAP and $\mathrm{PaCO}_{2}$ did not differ significantly among moments or between groups $\mathrm{G} 100$ and $\mathrm{G} 60$ (Table 1). $\mathrm{PaO}_{2}$ values in G100 were significantly greater than the means in G60 throughout the entire procedure (Table 1).

\section{DISCUSSION}

Before the induction of anesthesia, BIS was recorded as suggested by Schnider et al. (1998). The BIS value of awake dogs was around 98 in this study, corroborating Guerrero (2003).

The BIS is a dimensionless EEG parameter derived from Fourier and bispectral calculations performed on artifact-free EEG data (March e Muir, 2005). However, the EEG tracings have been shown to be altered by hypercapnia states, sedatives, hypoxia, ischemia and intracranial hypertension (Jordan, 1999). Thus, to study the effects of different $\mathrm{FiO}_{2}$ on bispectral index, it was important to avoid hypercapnia and hypoxia states.

In patients with increased ICP, the mechanical positive pressure ventilation should be immediately available and instituted at induction, being recommended to maintain the normocapnia (Armitage-Chan et al., 2007; Harvey et al., 2007). However, there is no consideration about which is the best inspired oxygen fraction to use in these cases. In this study, $\mathrm{FiO}_{2}$ of 1.0 was chosen because $100 \%$ of the oxygen has often been used during the anesthesia procedure (Leite, 2003; Paula et al., 2010). However, Nunes et al. (2008), in a study with dogs submitted to CRI of propofol $\left(0.7 \mathrm{mg} \cdot \mathrm{kg}^{-1} \cdot\right.$ minute $\left.^{-1}\right)$ and maintained in spontaneous breathing with different $\mathrm{FiO}_{2}$ (1.0, $0.8,0.6,0.4$ and 0.21$)$, concluded that $60 \%$ of the oxygen should be used. So, due to this information, $\mathrm{FiO}_{2}=0.6$ was chosen. 
Table 1. Means and standard deviations (Mean \pm SD) of ICP, CPP, MAP, ETCO $, \mathrm{PaO}_{2}, \mathrm{PaCO}_{2}, \mathrm{BIS}$, EMG, SQI, and SR in dogs with high intracranial pressure, submitted to a continuous infusion of propofol $\left(0.6 \mathrm{mg} \cdot \mathrm{kg}^{-1} \cdot\right.$ minute $\left.{ }^{-1}\right)$ and maintained under controlled ventilation with $\mathrm{FiO}_{2}=1(\mathrm{G} 100)$ or $\mathrm{FiO}_{2}=0.6$ (G60)

\begin{tabular}{|c|c|c|c|c|c|c|c|}
\hline \multirow{2}{*}{ Parameters } & \multirow{2}{*}{ Groups } & \multicolumn{6}{|c|}{ Times } \\
\hline & & Baseline & T0 & T15 & T30 & T45 & T60 \\
\hline \multirow{2}{*}{$\begin{array}{c}\mathrm{ICP} \\
(\mathrm{mm} \mathrm{Hg})\end{array}$} & G100 & $15 \pm 5$ & $22 \pm 6$ & $21 \pm 6$ & $22 \pm 7$ & $22 \pm 7$ & $23 \pm 8$ \\
\hline & G60 & $13 \pm 4$ & $18 \pm 5$ & $19 \pm 6$ & $18 \pm 4$ & $17 \pm 5$ & $18 \pm 6$ \\
\hline \multirow{2}{*}{$\begin{array}{c}\mathrm{CPP} \\
(\mathrm{mm} \mathrm{Hg})\end{array}$} & G100 & $81 \pm 11$ & $79 \pm 8$ & $74 \pm 11$ & $72 \pm 11$ & $71 \pm 12$ & $74 \pm 12$ \\
\hline & G60 & $91 \pm 14$ & $87 \pm 21$ & $85 \pm 19$ & $86 \pm 20$ & $84 \pm 20$ & $83 \pm 21$ \\
\hline \multirow{2}{*}{$\begin{array}{c}\text { MAP } \\
(\mathrm{mm} \mathrm{Hg})\end{array}$} & G100 & $97 \pm 11$ & $101 \pm 8$ & $96 \pm 10$ & $95 \pm 10$ & $92 \pm 10$ & $97 \pm 9$ \\
\hline & G60 & $104 \pm 16$ & $105 \pm 19$ & $104 \pm 17$ & $104 \pm 17$ & $101 \pm 18$ & $101 \pm 18$ \\
\hline \multirow{2}{*}{$\begin{array}{c}\mathrm{ETCO}_{2} \\
(\mathrm{~mm} \mathrm{Hg})\end{array}$} & G100 & $38 \pm 2$ & $38 \pm 2$ & $38 \pm 2$ & $38 \pm 2$ & $37 \pm 3$ & $38 \pm 2$ \\
\hline & G60 & $37 \pm 2$ & $37 \pm 2$ & $37 \pm 3$ & $37 \pm 3$ & $37 \pm 3$ & $36 \pm 2$ \\
\hline \multirow{2}{*}{$\begin{array}{c}\mathrm{PaO}_{2} \\
(\mathrm{~mm} \mathrm{Hg})\end{array}$} & G100 & - & $521 \pm 63 \mathrm{~A}$ & $543 \pm 35 \mathrm{~A}$ & $534 \pm 45 \mathrm{~A}$ & $530 \pm 21 \mathrm{~A}$ & $516 \pm 45 \mathrm{~A}$ \\
\hline & G60 & - & $312 \pm 16 \mathrm{~B}$ & $305 \pm 19 B$ & $299 \pm 22 B$ & $302 \pm 15 B$ & $302 \pm 21 B$ \\
\hline \multirow{2}{*}{$\begin{array}{c}\mathrm{PaCO}_{2} \\
(\mathrm{~mm} \mathrm{Hg})\end{array}$} & G100 & - & $42 \pm 4$ & $44 \pm 4$ & $42 \pm 4$ & $44 \pm 5$ & $43 \pm 7$ \\
\hline & G60 & - & $42 \pm 5$ & $44 \pm 5$ & $44 \pm 4$ & $43 \pm 4$ & $41 \pm 4$ \\
\hline \multirow[t]{2}{*}{ BIS } & G100 & $75 \pm 12$ & $70 \pm 8$ & $72 \pm 9$ & $70 \pm 8$ & $64 \pm 7$ & $67 \pm 3$ \\
\hline & G60 & $74 \pm 10$ & $71 \pm 7$ & $70 \pm 7$ & $67 \pm 7$ & $69 \pm 5$ & $70 \pm 6$ \\
\hline EMG & G100 & $41 \pm 8$ & $39 \pm 6$ & $38 \pm 6$ & $36 \pm 6$ & $35 \pm 4$ & $37 \pm 4$ \\
\hline$(\mathrm{db})$ & G60 & $39 \pm 5$ & $38 \pm 7$ & $36 \pm 6$ & $36 \pm 6$ & $37 \pm 6$ & $36 \pm 8$ \\
\hline SQI & G100 & $97 \pm 4$ & $96 \pm 5$ & $97 \pm 3$ & $96 \pm 5$ & $94 \pm 7$ & $95 \pm 7$ \\
\hline$(\%)$ & G60 & $98 \pm 3$ & $98 \pm 3$ & $98 \pm 2$ & $98 \pm 2$ & $99 \pm 2$ & $99 \pm 2$ \\
\hline SR & G100 & $1 \pm 2$ & $0 \pm 0$ & $0 \pm 0$ & $0 \pm 0$ & $2 \pm 2$ & $0 \pm 0$ \\
\hline$(\%)$ & G60 & $0 \pm 0$ & $0 \pm 0$ & $0 \pm 0$ & $0 \pm 0$ & $0 \pm 0$ & $0 \pm 0$ \\
\hline
\end{tabular}

Values did not differ within each row. Means with different letters within each column differ significantly from one another using Morrison's multivariate statistical methods $(\mathrm{p}<0.05)$.

ICP, intracranial pressure; CPP, cerebral perfusion pressure; BIS, bispectral index; EMG, electromyographic activity; $\mathrm{SQI}$, signal quality index; SR, suppression ratio; MAP, mean arterial pressure; $\mathrm{ETCO}_{2}$ End-tidal carbon dioxide, $\mathrm{PaO}_{2}$ arterial oxygen partial pressure and $\mathrm{PaCO}_{2}$, arterial carbon dioxide partial pressure.

Before the occlusion of the jugular vein (Baseline), ICP values were within the range of values considered normal by Plochl et al. (1998) and Johnston et al. (1991) (Table 1). Therefore, with normal ICP, the EEG and consequently BIS were influenced only by $\mathrm{FiO}_{2}$, because at this time normocapnia state was observed (Table 1). However, no differences in BIS were registered with use of different $\mathrm{FiO}_{2}$, corroborating Lopes et al. (2008b).

The ICP values registered at baseline (Table 1) were lower than means observed by Leite (2003). This author registered ICP at $17 \pm 8 \mathrm{mmHg}$ and $\mathrm{ETCO}_{2}$ at $58 \pm 11 \mathrm{mmHg}$ in dogs subjected to continuous infusion of propofol $\left(0.55 \pm 0.15 \mathrm{mg} \cdot \mathrm{kg}^{-1} \cdot \mathrm{minute}^{-1}\right) \quad$ and breathing spontaneously $\left(\mathrm{FiO}_{2}=1.0\right)$. It differed from this study because controlled ventilation was used to maintain the dogs in normocapnia (Table 1), given that a hypercapnia state increases ICP (Shenkin e Bouzarth, 1970).

Obstruction by occlusion of jugular veins can rapidly cause increase in ICP (Harvery et al., 2007). In both groups, there was not difference between baseline values and mean at $\mathrm{T} 0$, but the ICP increase was clinically significant (46.67\% in $\mathrm{G} 100$ and $38.46 \%$ in G60). Thus, in this study, at M0 the dogs had high ICP according to the definition of Plochl et al. (1998) and Johnston et al. (1991). Although the EEG tracings have been shown to be altered by intracranial hypertension (Jordan, 1999), the BIS means registered at baseline (Table 1) did not differ from the values observed in other moments. So this suggests that high ICP did not impair the BIS monitoring. Besides, Lopes et al. (2008b) observed values of BIS between 62 and 68 for $\mathrm{FiO}_{2}=1$, and between 62 and 74 for $\mathrm{FiO}_{2}=0.6$ in healthy 
dogs. The data obtained by these authors was close to the mean recorded in this study.

Besides, several $\mathrm{FiO}_{2}$ did not cause changes in the ICP means (Table 1), possibly because of the normocapnia obtained by controlled ventilation. The application of mechanical ventilation sought to minimize changes in the blood concentration of $\mathrm{CO}_{2}$, which can have some direct influence on ICP and CPP, because hypercapnia can impair cerebral autoregulation (McCulloch et al., 2000; Harvey et al., 2007). On the other hand, hypocapnia decreases both the ICP (Shenkin e Bouzarth, 1970) and the cerebral blood volume (Smith et al., 1970).

The stability of ICP during the continuous infusion of propofol was also observed by Paula et al. (2010), who concluded that propofol administration does not change ICP and maintains the cerebral perfusion and autoregulation. Moreover, Mckeage and Perry (2003) mentioned that in normovolemic patients with stable hemodynamic states, propofol conserves or decreases ICP, while maintaining CPP.

According to Steiner and Andrews (2006), the normal interval for CPP is between 50 and 150 $\mathrm{mmHg}$, hence, values recorded in this study are within physiological intervals (Table 1). Wong (2000) believes that CPP needs to remain between 60 and $70 \mathrm{mmHg}$ or above these values to maintain adequate cerebral blood flow. In this study, in both groups, CPP indicated no presence of ischemia that could change EEG tracings (Jordan, 1999). Besides, the BIS may also have reflected changes of cerebral perfusion (Cavus et al., 2010). Thus, in this study, it is possible to correlate CPP stability to the maintenance of BIS values.

This CPP stability was attributed to MAP constancy, because the influence of mean arterial pressure in CPP is three to four times more significant than in ICP. Therefore, the MAP is the most important factor in preserving CPP (Sponheim et al., 2003).

Observing other factors that might affect cerebral autoregulation, mean arterial pressures were within 60 and $140 \mathrm{mmHg}$. In healthy animals this limit does not cause changes to this system
(Harvery et al., 2007). Furthermore, there were no differences between groups regarding this parameter (Table 1).

In this study $\mathrm{PaCO}_{2}$ was recorded from $\mathrm{T} 0$ and the $\mathrm{ETCO}_{2}$ was observed before the temporary ligation of the jugular vein. $\mathrm{PaCO}_{2}$ values did not exceed the physiological limits (35 to $45 \mathrm{mmHg}$ ) (Haskins, 2004), or $\mathrm{ETCO}_{2}$ means (Table 1). Thus, this parameter did not influence the bispectral index monitoring in this study, corroborating Mi et al. (1998). These authors found that $\mathrm{PaCO}_{2}$ of 24 to $46 \mathrm{mmHg}$ did not interfere in the monitoring of the BIS' anesthetic depth.

McCulloch et al. (2000) observed that $\mathrm{PaCO}_{2}$ equals to $61 \pm 4 \mathrm{mmHg}$ impaired cerebral auto regulation in patients anesthetized with propofol. Lopes et al. (2008b) suggested that high $\mathrm{PaCO}_{2}$ recorded in their study caused changes in cerebral auto regulation. The values obtained by these authors were higher than those registered in this study (Table 1), because the mechanical ventilation allowed stabilizing capnometry. Thus, the cerebral autoregulation was not impaired in this study. This can be confirmed by the stability of ICP and CPP. Moreover, in patients with intracranial disease, comparisons of propofol and volatile anesthetics (sevoflurane and isoflurane) have demonstrated improved cerebral perfusion and better maintenance of pressure auto regulation when total intravenous anesthesia was used (Armitage-Chan et al., 2007).

The $\mathrm{PaO}_{2}$ depends on the $\mathrm{FiO}_{2}$, ventilation and ventilation-perfusion relationship. In anesthetized dogs the estimated $\mathrm{PaO}_{2}$ is 4 to 5 times the supplied $\mathrm{FiO}_{2}$ (Robertson, 2004), which coincides with this study's data. The difference between the $\mathrm{PaO}_{2}$ values with G100 and G60 (Table 1) can be attributed to the different $\mathrm{FiO}_{2}$ used in these groups. In both groups the mean $\mathrm{PaO}_{2}$ was above $50 \mathrm{mmHg}$. According to Harvey et al. (2007), $\mathrm{PaO}_{2}$ values below this level provide a major increase in $\mathrm{CBF}$ owing to the protective effect of the brain whenever there is low oxygenation. Thus, in this study, EEC tracing was not impaired by hypoxia (Jordan, 1999), which does not have a strong effect on BIS (Ikeda et al., 2009). 
Additionally, the bispectral index stability observed (Table 1) can also be attributed to the use of the same rates of infusion of propofol in both groups. Lopes et al. (2008a) reported that BIS correlates well with the dose, respectively, when propofol is administered alone. Lopes et al. (2008b) did not record any differences in BIS values among dogs subjected to a continuous infusion of propofol $\left(0.7 \mathrm{mg} \cdot \mathrm{kg}^{-1} \cdot\right.$ minute $\left.^{-1}\right)$ breathing spontaneously with $\mathrm{FiO}_{2}$ of 1 or 0.6 , corroborating this study.

The stability recorded for SQI, EMG and SR parameters corroborated Lopes et al. (2008b). In terms of EMG and SQI, the first parameter's values were below 40 and SQI means were above 94. These results demonstrated more reliable BIS values, corroborating the following authors: Guerrero (2003), who used SQI values above 90, EMG below 30, and SR of 0; Lopes et al. (2008a), who obtained EMG values below 43 and SQI above 92; and Lopes et al. (2008b), who recorded SQI means above 84 and EMG below 40. These parameters are important because there is a reported increase in BIS values, due to high eletromiographic activity, which was confirmed by high EMG values (Bruhn et al., 2000). According to Hatschbach et al. (2006), there is a correlation between EMG and BIS values.

For SQI, EMG and SR it was possible to affirm that high ICP did not impair these parameters, as well as affirming that the use of different $\mathrm{FiO}_{2}$ was not able to change these variables, corroborating Lopes et al. (2008b).

In conclusion, in dogs with mildly elevated ICP anesthetized with continuous infusion of propofol and controlled ventilation, bispectral index monitoring showed to be efficient and trustful. Besides, different $\mathrm{FiO}_{2}$ (1 or 0.6) did not influence the measures of anesthetic depth by bispectral index.

\section{ACKNOWLEDGEMENTS}

The authors would like to thank Fundação de Amparo à Pesquisa do Estado de São Paulo FAPESP, for the financial support and scholarship.

\section{REFERENCES}

ARMITAGE-CHAN, E.A.; WETMORE, L.A.; CHAN, D.L. Anesthetic management of the head trauma patient. J. Vet. Emerg. Crit. Care, v.17, p.5-14, 2007.

BRUHN, J.; BOUILLON, T.W.; SHAFER, S.L. Electromyographic activity falsely elevates the bispectral index. Anesthesiology, v.92, p.14851487, 2000.

CAVUS, E.; MEYBOHM, P.; DOERGES, V. et al. Effects of cerebral hypoperfusion on bispectral index: a randomised, controlled animal experiment during haemorrhagic shock. Resuscitation, v.81, p.1183-1189, 2010.

CURI, P.R. Análise de medidas repetidas em experimentos biológicos. Rev. Bras. Estat., v.41, p.137-150, 1980.

GREENFIELD, L.J.; EBERT, P.A.; BENSON, D.W. Effect of positive ventilation on surface tension properties of lung extracts. Anesthesiology, v.25, p.312-316, 1964.

GUERRERO, P.N.H. Influência do monitoramento do Índice Biespectral sobre o comportamento de variáveis cardiorrespiratórias e consumo de sevoflurano, em cães. 2003, 65f. Dissertação (Mestrado em Cirurgia Veterinária) - Faculdade de Ciências Agrárias e Veterinárias, Universidade Estadual Paulista, Jaboticabal, SP.

GUERRERO, P.N.H.; NUNES, N. Monitoramento do índice bispectral em cães. Semina, v.24, p.163-170, 2003.

HARVEY, R.C.; GREENE, S.A.; THOMAS W. Neurological disease. In: TRANQUILLI, W.J.; THURMON, J.C.; GRIMM, K.A. (Eds). Lumb \& Jones' Veterinary anesthesia and analgesia. 4th ed. Oxford: Blackwell Publising, 2007. p.903913.

HASKINS, S.C. Interpretation of blood gas measurements. In: KING, L.G. (Ed). Textbook of respiratory disease in dogs and cats. 1sd ed. Philadelphia: Saunders, 2004. p.181-192.

HASKINS, S.C. Monitoring anesthetized patients. In: TRANQUILLI, W.J.; THURMON, J.C.; GRIMM, K.A. (Eds). Lumb \& Jones' Veterinary anesthesia and analgesia. 4th ed. Oxford: Blackwell Publising, 2007. p.533-558. 
HATSCHBACH, E.; MASSONE, F.; SANTOS, G.J.V. et al. Parametria of midazolam or diazepam combination in dogs pretrated with atropine and treated with dexmedetomidine and ketamine. Ciên. Rur., v.36, p.536-543, 2006.

HEMMERLING, T.M.; MIGNEAULT, B. Falsely increased bispectral index during endoscopic shouder surgery attributed to interferences with the endoscopic shaver device. Anesth. Analg., v.95, p.1678-1679, 2002.

HOPPER, K.; HASKINS, S.C.; KASS, P.H. et al. Indications, management and outcome of long-term positive pressure ventilation in dogs and cats: 148 cases (1990-2001). J. Am. Vet. Med. Assoc., v.230, p.64-75, 2007.

IKEDA, T.; YAMADA, S.; IMADA, T. et al. Influence of hypobaric hypoxia on bispectral índex and spectral entropy in volunteers. Acta Anaesthesiol. Scand., v.53, p.891-894, 2009.

JOHNSTON, W.E.; VINTEN-JOHANSEN, J.; DEWITT, D.S. et al. Cerebral perfusion during canine hypothermic cardiopulmonary bypass effect of arterial carbon dioxide tension. Ann. Thorac. Surg., v.52, p.479-489, 1991.

JORDAN, K.G. Continuous EEG monitoring in the neuroscience intensive care unit and emergency department. J. Clin. Neurophysiol., v.16, p.14-39, 1999.

LEITE, A.V. Efeitos do propofol ou sevoflurano sobre a hemodinâmica, ventilometria a parâmetros intracranianos, em cães submetidos à administração subaracnóidea de iohexol. 2003. 74f. Dissertação (Mestrado em Cirurgia Veterinária) - Faculdade de Ciências Agrárias e Veterinárias, Universidade Estadual Paulista, Jaboticabal, SP.

LOPES, P.C.F.; NUNES, N. Atelectasia pulmonar em cães durante anestesia geral. Cienc. Rural, v.40, p.246-253, 2010.

LOPES, P.C.F.; NUNES, N.; CARARETO, R. et al. Efeitos de diferentes frações inspiradas de oxigênio sobre a dinâmica respiratória em cães submetidos à infusão contínua de propofol e mantidos em ventilação espontânea. Braz. J. Vet. Res. Anim. Sci., v.44, p.30-37, 2007.

LOPES, P.C.F.; NUNES, N.; PAULA, D.P. et al. Bispectral index in dogs at three intravenous infusion rates of propofol. Vet. Anesth. Analg., v.35, p.228-231, 2008a.
LOPES, P.C.F.; NUNES, N.; NISHIMORI, C.T.D. et al. Efeitos de diferentes frações inspiradas de oxigênio no índice biespectral em cães submetidos à infusão contínua de propofol. Arq. Bras. Med. Vet. Zootec., v.60, p.359-366, 2008b.

MARCH, P.A.; MUIR, W.W. Bispectral analysis of the electroencephalogram: a review of its development and use in anesthesia. Vet. Anesth. Analg., v.32, p.241-255, 2005.

McCULLOCH, T.J.; VISCO, E.; LAM, A.M. Graded hypercapnia and cerebral autoregulation during sevoflurane or propofol anesthesia. Anesthesiology, v.93, p.1205-1209, 2000.

MCKEAGE, K.; PERRY, C.M. Propofol: a review of this use in intensive care sedations of adults. CNS Drugs, v.17, p.235-272, 2003.

MI, W.D.; SAKAI, T.; TAKAHASHI, S. et al. The influence of changes in $\mathrm{PaCO}_{2}$ on bispectral index, spectral edge frequency and median frequency during propofol/fentanyl anesthesia. Anesth. Analg., v.86, p.548S, 1998.

MORIMOTO, Y.; MONDEN, Y.; OHTAKE, K. et al. The detection of cerebral hypoperfusion with bispectral index monitoring during general anesthesia. Anesth. Analg., v.100, p.158-161, 2005.

MORRISON, D.F. Multivariate statistical methods. New York: MaC Grows Hill Book, 1967. 388p.

NUNES, N.; LOPES, P.C.F.; SANTOS, P.S.P. et al. Hemodinâmica de diferentes frações inspiradas de oxigênio em cães submetidos à infusão contínua de propofol sob ventilação espontânea Cien. Rur., v.38, p.729-735, 2008.

PAULA, D.P.; NUNES, N.; NISHIMORI, C.T.D. et al. Efeitos da infusão contínua de propofol ou etomidato sobre variáveis intracranianas em cães. Arq. Bras. Med. Vet. Zootec., v.62, p.302-308, 2010.

PLOCHL, W.; COOK, D.J.; ORSZULAK, T.A. et al. Critical cerebral perfusion pressure during tepid heart surgery in dogs. Ann. Thorac. Surg., v.66, p.118-124, 1998. 
REZENDE, M.L. Efeitos do sevofuorano e do desfluorano sobre variáveis intracranianas $e$ hemodinâmicas em cães. 2004. 102f. Tese (Doutorado em Cirurgia Veterinária) Faculdade de Ciências Agrárias e Veterinárias, Universidade Estadual Paulista, Jaboticabal, SP.

ROBERTSON, S.A. Oxigenação e ventilação. In: GREENE, S.A. (Ed). Segredos em anestesia veterinária e manejo da dor. Porto Alegre: Artmed, 2004. p.31-36.

ROSOW, C.; MANBERG, P.J. Bispectral index monitoring. Anesthesiol. Clin. N. Am., v.19, p.947-966, 2001.

SCHNIDER, T.W.; DRMED, L.; MARTIN DRMED, P.F. et al. Unreasonably low bispectral values in a volunteer with genetically determined low-voltage electroencephalographic signal. Anesthesiology, v.89, p.1607-1608, 1998.

SHENKIN, H.A.; BOUZARTH, W.F. Clinical methods of reducing intracranial pressure. $N$. Engl. J. Med., v.282, p. 1465-1471, 1970.
SMITH, A.L.; NEUFELD, G.R.; OMINSKY, A.J. et al. Interrelations among cerebral blood flow, mean transit time, and vascular volume. Fed. Proc., v.29, p.519, 1970.

SPONHEIM, S.; SKRAASTAD, O; HELSETH, E. et al. Effects of 0.5 and 1.0 MAC isoflurane, sevoflurane and desflurane on intracranial and cerebral perfusion pressures in children. Acta Anaesthesiol. Scand., v.47, p.932-938, 2003.

STEINER, L.A.; ANDREWS, J.D. Monitoring the injured brain: ICP and CBF. Brit. J. Anaesth., v.97, p.26-38, 2006.

STRANDBERG, A.; TOKICS, L.; BRISMAR, B. et al. Atelectasis during anaesthesia and in the postoperative period. Acta Anaesthesiol. Scand., v.30, p.154-158, 1986.

WONG, F. Prevention of secondary brain injury. Crit. Care Nurse, v.20, p.18-27, 2000. 